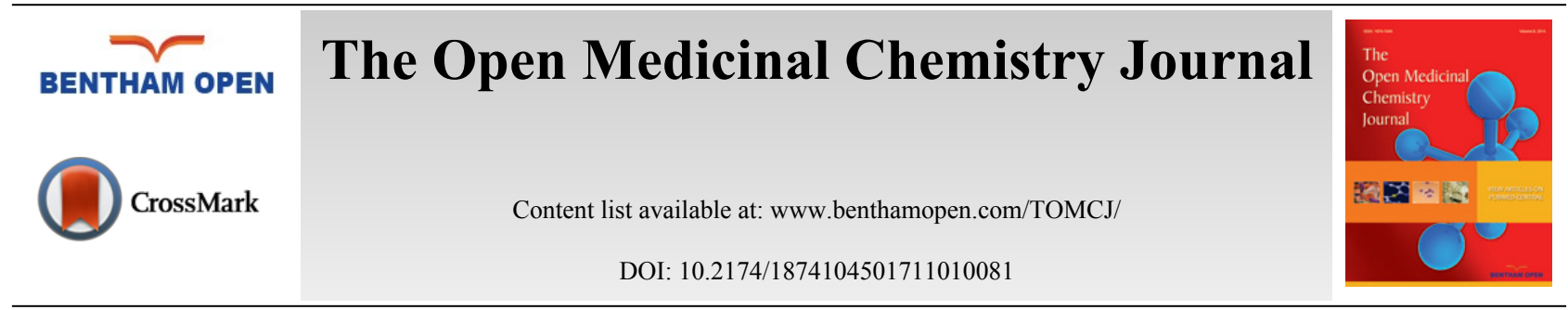

RESEARCH ARTICLE

\title{
Synthesis and Anticancer Evaluation of Some New 3-Benzyl-4,8- Dimethylbenzopyrone Derivatives
}

\author{
Sohair L. El-Ansary ${ }^{1,2}$, Doaa E. Abdel Rahman ${ }^{1}$ and Lina M. A. Abdel Ghany ${ }^{2, *}$ \\ ${ }^{\text {I}}$ Department of Pharmaceutical Chemistry, Faculty of Pharmacy, Cairo University, Kasr El-Aini Street, Cairo 11562, \\ Egypt \\ ${ }^{2}$ Department of Pharmaceutical Chemistry, Faculty of Pharmacy, Misr University for Science and Technology, Misr, \\ Egypt
}

Received: March 30, 2017

Revised: April 4, 2017

Accepted: June 20, 2017

\section{Abstract:}

Introduction:

New benzopyrone derivatives such as Schiff's like compounds, acetohydrazides or substituted with oxadiazole or pyrazole heterocycles were synthesized from parent acid hydrazide compound $\mathbf{3}$.

\section{Methods and Materials:}

Structures of the synthesized compounds were elucidated using IR, NMR and mass spectroscopy. All the synthesized derivatives were selected by National Cancer Institute (NCI), Bethesda, and evaluated for their in vitro anticancer activity in the full NCI 60 cell lines panel assay.

\section{Results and Conclusion:}

Schiffs like compounds $\mathbf{4 a}, \mathbf{b}$ and $\mathbf{c}$ were found to have good growth inhibition \% against numerous cell lines that belong mainly to leukemia, non-small cell lung, CNS and breast Cancer subpanels.

Keywords: Benzopyrones, Acid hydrazide, Oxadiazoles, Pyrazoles, Anticancer.

\section{INTRODUCTION}

Cancer can be defined as a disease in which a group of abnormal cells grow uncontrollably disregarding the normal rules of cell division. Normal cells are constantly subjected to signals that dictate whether the cell should divide, differentiate into another cell or die. Cancer cells develop a degree of autonomy from these signals, resulting in uncontrolled growth and proliferation. If this proliferation is allowed to continue and spread, it can be fatal. In fact, almost $90 \%$ of cancer- related deaths are due to tumor spreading or dissemination [1]. Phenomenal advances in cancer research have given us insight into how cancer cells develop this autonomy. Now, cancer is defined as a disease that involves changes or mutations in the cell genom, the somatic mutation theory has been the prevailing paradigm in cancer research and its premise is that cancer is a disease of cell proliferation caused by mutation in genes that control proliferation and the cell cycle [2].

Although advances in the field of chemo-preventive and therapeutic medicine have been made regularly over the last ten years, the search for novel anticancer treatments continues as it became an urgency to develop new anticancer agents with fewer side effects.

\footnotetext{
* Address correspondence to this authors at the Department of Pharmaceutical Chemistry, Faculty of Pharmacy, Misr University For Science and Technology, Al-Motamayez District, P.O.Box: 77, Misr, Egypt; Tel: +202- 38247455, 38247456, 38247457; E-mails: dr.linaamin@gmail.com, lina.amin@must.edu.eg
} 
Benzopyran-2-one comprises a group of natural compounds found in a variety of plant sources [3]. Benzopyrones were recognized to possess a broad spectrum of antitumor activity following different mechanisms as 667-Coumarate (Fig. 1A) that acts as Sulphatase inhibitors [4] and Carbonic anhydrase II enzyme inhibitors [5] while other benzopyrones were reported as Histone deacetylase (HDAC) inhibitors as Fig. (1B) [6]. Moreover, geiparvarin (Fig. 1C), a naturally occurring coumarin has been shown to possess a significant inhibition for cell lines including sarcoma 180, lewis lung carcinoma, P-388 lymphocytic leukemia and walker 256 carcinosarcoma [7]. Furthermore, literature survey revealed several heterocycles as oxadiazole [8], pyrazole [9], dimethyl pyrazole [10], amino pyrazole [11], and pyrazolone [12] all possessed reported antitumor effect.<smiles>Cc1cc(=O)oc2ccc(OS(N)(=O)=O)cc12</smiles>

$\mathbf{A}$<smiles>COc1ccc2c(C(=O)/C=C/c3ccccc3)cc(=O)oc2c1</smiles>

B<smiles>CC(=CCOc1ccc2ccc(=O)oc2c1O)C1=CC(=O)CC1</smiles>

C

Fig. (1). Antitumor benzopyrones.

These findings have encouraged us to design and synthesize compounds comprised of the benzopyran-2-one scaffold as Schiffs like compounds, acetohydrazides or substituted with oxadiazole, pyrazole heterocycles. The newly synthesized compounds were selected by National Cancer Institute (NCI), Bethesda, MD, U.S.A., for in vitro one dose testing in the full NCI 60 cell lines panel assay.

\section{MATERIALS AND METHODS}

\subsection{Chemistry}

Melting points were determined by open capillary tube method using Stuart SMP10 melting point apparatus and were uncorrected. Microanalyses were carried out at The Regional Center for Mycology and Biotechnology, Al-Azhar University. Infrared Spectra were recorded as potassium bromide discs on Schimadzu FT-IR 8400S spectrophotometer (Shimadzu, Kyoto, Japan) and Bruker FT-IR spectrophotometer and expressed in wave number $v_{\max }\left(\mathrm{cm}^{-1}\right)$. The ${ }^{1} \mathrm{H}$ NMR spectra were recorded on a Bruker AVANCE III spectrometer at $400 \mathrm{MHz}$, in dimethylsulphoxide (DMSO- $d_{6}$ ). Chemical Shifts are quoted in $\delta$ as parts per million (ppm) downfield from tetramethylsilane (TMS) as internal standard and $J$ values are reported in Hz. Mass spectra were performed as EI at 70eV on Hewlett Packard Varian (Varian, Polo, USA) and Shimadzu Gas Chromatograph Mass spectrometer-QP 1000 EX and direct inlet unit of Shimadzu GC/MSQP5050A at 70eV. TLC were carried out using Macherey-Nagel Alugram Sil G/UV $\mathrm{U}_{254}$ silica gel plates with fluorescent indicator $\mathrm{UV}_{254}$ and chloroform:methanol (9.5:0.5) as the eluting system and the spots were visualized at $366,254 \mathrm{~nm}$ by UV Vilber Lourmat 77202 (Vilber, Marne La Vallee, France).

\subsubsection{3-Benzyl-4,8-dimethyl-7-hydroxy-2H-1-benzopyran-2-one 1 (Scheme 1) was prepared as reported in literature} [13].

\subsubsection{Ethyl 2-(3-benzyl-4,8-dimethyl-2-oxo-2H-benzopyran-7-yl)oxyacetate 2 (Scheme 1).}

A mixture of 1 (28 g, $0.1 \mathrm{~mol})$, anhydrous potassium carbonate $(27.6 \mathrm{~g}, 0.2 \mathrm{~mol})$ and ethyl chloroacetate (14.64 g, $0.12 \mathrm{~mol})$ in dry acetone $(200 \mathrm{~mL})$ was heated under reflux with stirring for $24 \mathrm{~h}$. It was then made to cool down filtered and washed with acetone. The combined filtrate and washing were concentrated and filtered. The crude product was crystallized from ethanol to yield $36 \%$ of $2 . \mathrm{mp} 103-105{ }^{\circ} \mathrm{C}$. IR $v_{\max } \mathrm{cm}^{-1}: 3010$ (CH Ar), 2916 (CH aliphatic), 1705, $1685(2 \mathrm{C}=\mathrm{O}), 1602,1577,1492,(\mathrm{C}=\mathrm{C}) .{ }^{1} \mathrm{H}$ NMR (DMSO- $\left.d_{6}\right) \delta p p m: 1.22\left(\mathrm{t}, 3 \mathrm{H}, \mathrm{CH}_{2} \mathrm{CH}_{3}\right), 2.25\left(\mathrm{~s}, 3 \mathrm{H}, \mathrm{CH}_{3}\right.$ at $\left.\mathrm{C} 4\right)$, $2.42\left(\mathrm{~s}, 3 \mathrm{H}, \mathrm{CH}_{3}\right.$ at $\left.\mathrm{C} 8\right), 3.96\left(\mathrm{~s}, 2 \mathrm{H}, \mathrm{CH}_{2}\right), 4.18\left(\mathrm{q}, 2 \mathrm{H}, \mathrm{CH}_{2} \mathrm{CH}_{3}\right), 4.96\left(\mathrm{~s}, 2 \mathrm{H}, \mathrm{OCH}_{2}\right), 6.98(\mathrm{~d}, 1 \mathrm{H}, J=9.0 \mathrm{~Hz}, \mathrm{H}-6 \mathrm{Ar})$, 7.17 (t, 1H, H-4' Ar), 7.23 (t, 2H, H-3',5' Ar), 7.28 (d, 2H, J=7.4 Hz, H-2',6' Ar), 7.62 (d, 1H, J=8.9 Hz, H-5 Ar). MS m/z \%: $366\left(\mathrm{M}^{+}\right)$100\%. $\mathrm{C}_{22} \mathrm{H}_{22} \mathrm{O}_{5}$ (366.41): Anal. Calcd. for Calc. C, 72.12; H, 6.05. Found: C, 72.48; H, 6.17. 


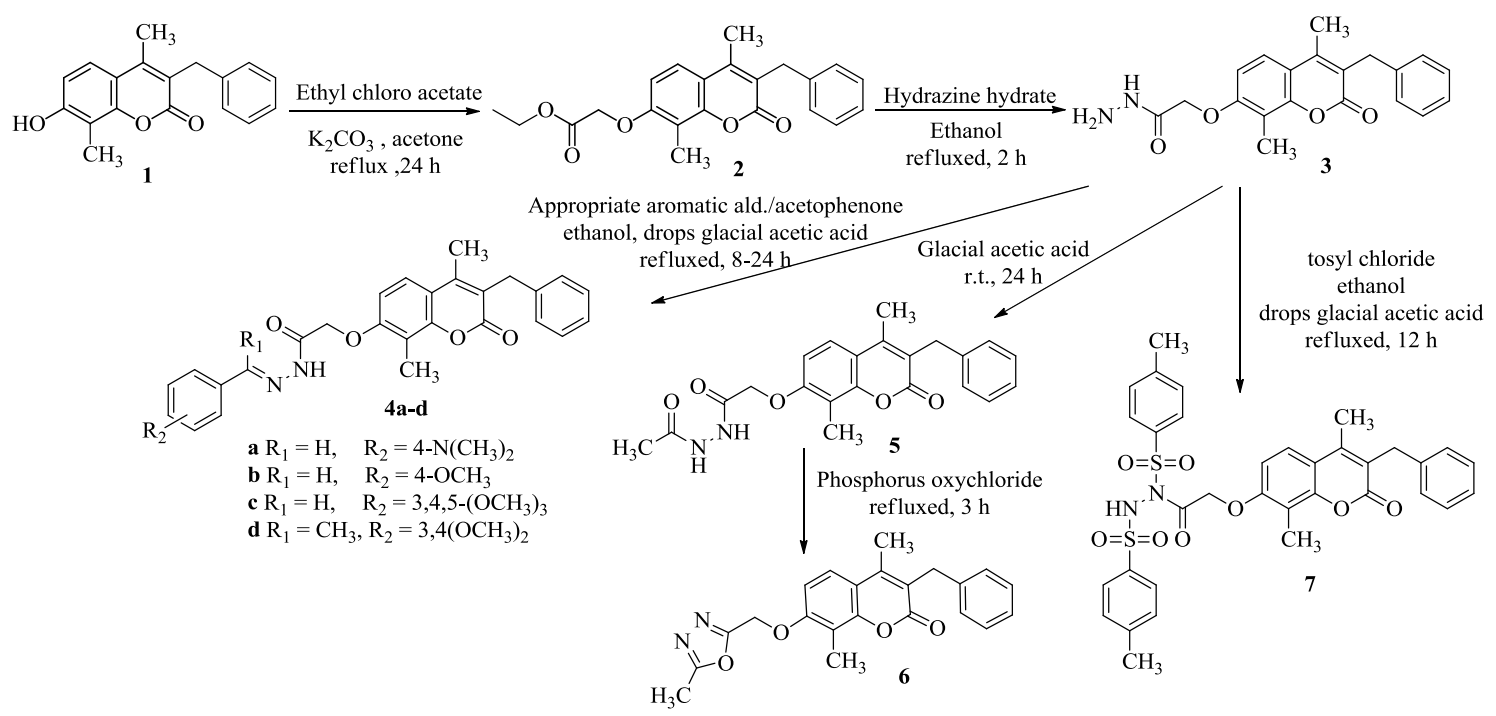

Scheme (1). Synthesis of Sciffs like compounds 4a-d,acetohydrazide 5,oxadiazole 6 and methylphenylsulphonyl derivative 7.

\subsubsection{2-(3-Benzyl-4,8-dimethyl-2-oxo-2H-benzopyran-7-yl)oxyacetohydrazide 3 (Scheme 1)}

A mixture of the ester compound $2(3.66 \mathrm{~g}, 0.01 \mathrm{~mol})$ and hydrazine hydrate $99 \%(1 \mathrm{~mL}, 0.02 \mathrm{~mol})$ in ethanol (30 $\mathrm{mL}$ ) was heated under reflux for $2 \mathrm{~h}$. The precipitate was filtered, washed with water and dried. The crude product was crystallized from acetic acid to yield $89 \%$ of 3. $\mathrm{mp} 243-245^{\circ} \mathrm{C}$. IR $v_{\max }, \mathrm{cm}^{-1}: 3502,3446,3180$ broad $\left(\mathrm{NH}_{2}, \mathrm{NH}^{2}, 3061\right.$ (CH Ar), 2929, 2854 (CH aliphatic), 1705, $1697(2 \mathrm{C}=\mathrm{O}), 1604,1495(\mathrm{NH}, \mathrm{C}=\mathrm{C}) .{ }^{1} \mathrm{H}$ NMR (DMSO- $\left.d_{6}\right) \delta p p m: 2.26(\mathrm{~s}$, $3 \mathrm{H}, \mathrm{CH}_{3}$ at C4), 2.43 (s, $3 \mathrm{H}, \mathrm{CH}_{3}$ at $\left.\mathrm{C} 8\right), 3.96\left(\mathrm{~s}, 2 \mathrm{H}, \mathrm{CH}_{2}\right), 4.35$ (br's, 2H, $\left.\mathrm{NH}_{2}\right), 4.65\left(\mathrm{~s}, 2 \mathrm{H}, \mathrm{OCH}_{2}\right), 6.96(\mathrm{~d}, 1 \mathrm{H}, J=9.0$ Hz, H-6 Ar), 7.17 (t, 1H, H-4' Ar), 7.23 (t, 2H, H-3',5' Ar), 7.28 (d, 2H, J= 7.4 Hz, H-2',6' Ar), 7.63 (d, 1H, J=8.92 Hz, H-5 Ar), 9.32 (s, $1 \mathrm{H}, \mathrm{NH})$. MS m/z \%:352 (M+) 75.48\%. Anal. Calcd. for $\mathrm{C}_{20} \mathrm{H}_{20} \mathrm{~N}_{2} \mathrm{O}_{4}$ (352.38): Calc.: C, 68.17; H, 5.72; N, 7.95. Found: C, 68.34; H, 5.87; N, 8.10.

\subsubsection{General procedure for synthesis of 2-(3-Benzyl-4,8-dimethyl-2-oxo-2H-benzopyran-7-yl)oxy-N'- (Substitutedbenzylidene)acetohydrazide 4a-d (Scheme 1)}

A mixture of acid hydrazide $3(0.01 \mathrm{~mol})$, appropriate aromatic aldehyde/acetophenone (0.01 mol) in ethanol (20 $\mathrm{mL}$ ) containing a few drops of acetic acid was heated under reflux for 18-24 h. The solvent was distilled under vacuum and the residue crystallized from ethanol.

\subsubsection{2-(3-Benzyl-4,8-dimethyl-2-oxo-2H-benzopyran-7-yl)oxy-N'-(4-dimethylaminobenzylidene)acetohydrazide 4a}

Yield 25\%. mp 64-67 ${ }^{\circ} \mathrm{C}$. IR $v_{\max } / \mathrm{cm}^{-1}: 3460(\mathrm{NH}), 3057$ (CH Ar), 2926 (CH aliphatic), 1710, 1693, (2C=O), 1600, 1643, 1554, 1494, (C=N, NH, C=C). ${ }^{1} \mathrm{H}$ NMR (DMSO-d 6 ) $\delta$ ppm: 2.26 (s, 3H, $\mathrm{CH}_{3}$ at C4), $2.42\left(\mathrm{~s}, 3 \mathrm{H}, \mathrm{CH}_{3}\right.$ at $\left.\mathrm{C} 8\right), 3.07$ $\left(\mathrm{s}, 6 \mathrm{H}, \mathrm{N}\left(\mathrm{CH}_{3}\right)_{2}\right), 3.96\left(\mathrm{~s}, 2 \mathrm{H}, \mathrm{CH}_{2}\right), 5.28\left(\mathrm{~s}, 2 \mathrm{H}, \mathrm{OCH}_{2}\right), 6.72(\mathrm{~d}, 1 \mathrm{H}, J=8.8 \mathrm{~Hz}, \mathrm{H}-6 \mathrm{Ar}), 6.79(\mathrm{~d}, 2 \mathrm{H}, J=8.9 \mathrm{~Hz}$, H-3", 5" Ar), 7.17 (t, 1H, H-4' Ar), 7.23 (t, 2H, H-3',5' Ar), 7.26 (d, 2H, J=7.4 Hz, H-2',6' Ar), 7.51 (d, $1 \mathrm{H}, J=8.7 \mathrm{~Hz}$, H-5 Ar), 7.69 (d, 2H, J=8.9 Hz, H-2",6" Ar), 7.89 (c, 1H, CH=N), 8.50 (s, 1H, NH). MS m/z\%: $483\left(\mathrm{M}^{+}\right) 11.33 \%$. Anal. Calcd. For $\mathrm{C}_{29} \mathrm{H}_{29} \mathrm{~N}_{3} \mathrm{O}_{4}$ (483.56): C, 72.03; H, 6.04; N, 8.69 Found: C, 72.19; H, 6.11; N, 8.85.

\subsubsection{2-(3-Benzyl-4,8-dimethyl-2-oxo-2H-benzopyran-7-yl)oxy-N'-(4-methoxybenzylidene)acetohydrazide 4b}

Yield 71\%. mp 221-223 ${ }^{\circ} \mathrm{C}$. IR $v_{\max } / \mathrm{cm}^{-1}: 3432(\mathrm{NH}), 3090(\mathrm{CH}$ Ar), 2967, 2927 (CH aliphatic), 1713 (2C=O), 1614, $1449(\mathrm{C}=\mathrm{N}, \mathrm{C}=\mathrm{C}) .{ }^{1} \mathrm{H}$ NMR (400 MHz, DMSO- $\left.d_{6}\right) \delta$ ppm: $2.27\left(\mathrm{~s}, 3 \mathrm{H}, \mathrm{CH}_{3}\right.$ at C4), $2.42\left(\mathrm{~s}, 3 \mathrm{H}, \mathrm{CH}_{3}\right.$ at $\left.\mathrm{C} 8\right), 3.80$ $\left(\mathrm{s}, 3 \mathrm{H}, \mathrm{OCH}_{3}\right), 3.96\left(\mathrm{~s}, 2 \mathrm{H}, \mathrm{CH}_{2}\right), 5.30\left(\mathrm{~s}, 2 \mathrm{H}, \mathrm{OCH}_{2}\right), 6.96(\mathrm{~d}, 1 \mathrm{H}, J=9.1 \mathrm{~Hz}, \mathrm{H}-6 \mathrm{Ar}), 6.99$ (d, 2H, J=8.7 Hz, H-3",5" Ar), 7.17 (t, 1H, H-4' Ar), 7.23 (t, 2H, H-3',5' Ar), 7.26 (d, 2H, J= 7.4 Hz, H-2',6' Ar), 7.60 (d, 1H, J= 8.9 Hz, H-5 Ar), 7.69 (d, 2H, J=8.7 Hz, H-2",6" Ar), 7.96 (c, 1H, CH=N), 11.54 (s, 1H, NH). MS m/z\%: $469\left(\mathrm{M}^{+}-1\right) 89.14 \%, 470$ (M+) 29.32\%. Anal. Calcd. For $\mathrm{C}_{28} \mathrm{H}_{26} \mathrm{~N}_{2} \mathrm{O}_{5}$ (470.52): C, 71.47; H, 5.57; N, 5.95. Found: C, 71.80; H, 5.64; N, 6.04. 
2.1.4.3. 2-(3-Benzyl-4,8-dimethyl-2-oxo-2H-benzopyran-7-yl)oxy-N'-(3,4,5-trimethoxybenzylidene)acetohydrazide 4c

Yield 86\%. mp 140-142 ${ }^{\circ} \mathrm{C}$. IR $v_{\max } / \mathrm{cm}^{-1}: 3203(\mathrm{NH}), 3062(\mathrm{CH} \mathrm{Ar}), 2958,2924$ (CH aliphatic), 1695, 1681 $(2 \mathrm{C}=\mathrm{O}), 1602,1566,1508,1492(\mathrm{C}=\mathrm{N}, \mathrm{NH}, \mathrm{C}=\mathrm{C}) .{ }^{1} \mathrm{H}$ NMR $\left(400 \mathrm{MHz}, \mathrm{DMSO}-d_{6}\right) \delta p p m: 2.27\left(\mathrm{~s}, 3 \mathrm{H}, \mathrm{CH}_{3}\right.$ at $\left.\mathrm{C} 4\right)$, $2.42\left(\mathrm{~s}, 3 \mathrm{H}, \mathrm{CH}_{3}\right.$ at $\left.\mathrm{C} 8\right), 3.70\left(\mathrm{~s}, 3 \mathrm{H}, \mathrm{OCH}_{3}\right), 3.82\left(\mathrm{~s}, 6 \mathrm{H}, 2 \mathrm{xOCH}_{3}\right), 3.97\left(\mathrm{~s}, 2 \mathrm{H}, \mathrm{CH}_{2}\right), 5.35\left(\mathrm{~s}, 2 \mathrm{H}, \mathrm{OCH}_{2}\right), 6.96(\mathrm{~d}, 1 \mathrm{H}$, $\mathrm{J}=8.9 \mathrm{~Hz}, \mathrm{H}-6 \mathrm{Ar}), 7.01$ (s, 2H, H-2"',6" Ar), 7.17 (t, 1H, H-4' Ar), 7.23 (t, 2H, H-3', 5' Ar), 7.26 (d, 2H, J= 7.4 Hz, H-2',6' Ar), 7.62 (d, 1H, J=8.8 Hz, H-5 Ar), $8.22(\mathrm{~s}, 1 \mathrm{H}, \mathrm{HC}=\mathrm{N}), 11.57(\mathrm{~s}, 1 \mathrm{H}, \mathrm{NH}) . \mathrm{MS} m / z^{\circ}: 530\left(\mathrm{M}^{+}\right) 34.00 \%$. Anal. Calcd. for $\mathrm{C}_{30} \mathrm{H}_{30} \mathrm{~N}_{2} \mathrm{O}_{7}$ (530.57): C, 67.91; H, 5.70; N, 5.28 Found: C, 68.17; H, 5.79; N, 5.39.

\subsubsection{2-(3-Benzyl-4,8-dimethyl-2-oxo-2H-benzopyran-7-vl)oxy-N'-[1- (3,4-dimethoxvphenvl) ethylidene] acetohvdrazide $4 d$}

Yield 30\%. mp 273-275 ${ }^{\circ} \mathrm{C}$. IR $v_{\max } / \mathrm{cm}^{-1}: 3188(\mathrm{NH}), 3059(\mathrm{CH} \mathrm{Ar}), 2931,2852(\mathrm{CH}$ aliphatic), 1710, 1697 $(2 \mathrm{C}=\mathrm{O}), 1604,1514,1490,(\mathrm{C}=\mathrm{N}, \mathrm{C}=\mathrm{C}) .{ }^{1} \mathrm{H}$ NMR $\left(\mathrm{DMSO}-d_{6}\right) \delta p p m: 2.25\left(\mathrm{~s}, 3 \mathrm{H}, \mathrm{CH}_{3}\right.$ at $\left.\mathrm{C} 4\right), 2.42(\mathrm{~s}, 3 \mathrm{H}, \mathrm{CH}$ at $\mathrm{C} 8)$, $2.53\left(\mathrm{~s}, 3 \mathrm{H}, \mathrm{N}=\mathrm{CCH}_{3}\right), 3.81\left(\mathrm{~s}, 3 \mathrm{H}, \mathrm{OCH}_{3}\right), 3.84\left(\mathrm{~s}, 3 \mathrm{H}, \mathrm{OCH}_{3}\right), 3.96\left(\mathrm{~s}, 2 \mathrm{H}, \mathrm{CH}_{2}\right), 4.96\left(\mathrm{~s}, 2 \mathrm{H}, \mathrm{OCH}_{2}\right), 6.97(\mathrm{~d}, 1 \mathrm{H}, J=$ 8.8 Hz, H-6 Ar), 7.06 (d, 1H, $J=8.4$ Hz, H-6"Ar), 7.17 (t, 1H, H-4' Ar), 7.23 (t, 2H, H-3', 5' Ar), 7.27 (d, $2 \mathrm{H}, J=7.4$ Hz, H-2',6' Ar), 7.44 (d, 1H, $J=5.9$ Hz, H-2" Ar), 7.60-7.64 (m, 3H, H-5,5"Ar, NH). MS m/z \%: $514\left(\mathrm{M}^{+}\right) 1.20 \%$. Anal. Calcd. for $\mathrm{C}_{30} \mathrm{H}_{30} \mathrm{~N}_{2} \mathrm{O}_{6}$ (514.57): C, 70.02; H, 5.88; N, 5.44. Found: C, 70.38; H, 5.94; N, 5.60.

\subsubsection{N'-Acetyl-2-(3-benzyl-4,8-dimethyl-2-oxo-2H-benzopyran-7-yl)oxyacetohydrazide 5 (Scheme 1)}

A suspension of acid hydrazide $3(1.83 \mathrm{~g}, 0.005 \mathrm{~mol})$ in glacial acetic acid (15 mL) was stirred at room temperature for $24 \mathrm{~h}$. The solvent was distilled under vacuum and the residue was crystallized from ethyl acetate to yield $98 \%$ of $\mathbf{5}$. mp 278-279 ${ }^{\circ} \mathrm{C}$. IR $v_{\max } \mathrm{cm}^{-1}:$ 3446, 3238 (2 NH), 3001 (CH Ar), 2922 (CH aliphatic), 1715, 1707 (3 C=O), 1653, 1602 , 1583, $1487(\mathrm{NH}, \mathrm{C}=\mathrm{C}) .{ }^{1} \mathrm{H} \mathrm{NMR}\left(\mathrm{DMSO}-d_{6}\right) \delta p p m: 1.88\left(\mathrm{~s}, 3 \mathrm{H}, \mathrm{COCH}_{3}\right), 2.24\left(\mathrm{~s}, 3 \mathrm{H}, \mathrm{CH}_{3}\right.$ at C4), $2.43\left(\mathrm{~s}, 3 \mathrm{H}, \mathrm{CH}_{3}\right.$ at C8), 3.96 (s, 2H, $\mathrm{CH}_{2}$ ), 4.76 (s, 2H, $\mathrm{OCH}_{2}$ ), 7.00 (d, 1H, J=9.0 Hz, H-6 Ar), 7.17 (t, 1H, H-4' Ar), 7.23 (t, 2H, H-3',5' Ar), 7.28 (d, 2H, $J=7.4$ Hz, H-2',6' Ar), 7.63 (s, 1H, J=8.8 Hz, H-5 Ar), 9.89 (s, 1H, NH), 10.04 (s, 1H, NH). MS m/z \%:394 $\left(\mathrm{M}^{+}\right)$100\%. Anal. Calcd. for $\mathrm{C}_{22} \mathrm{H}_{22} \mathrm{~N}_{2} \mathrm{O}_{5}$ (394.42): Calc.: C, 66.99; H, 5.62; N, 7.10. Found: C, 67.26; H, 5.71; N, 7.23 .

\subsubsection{3-Benzyl-4,8-dimethyl-7-(5-methyl-1,3,4-oxadiazol-2-yl)methoxy-2H-benzopyran-2-one 6 (Scheme 1)}

A mixture of compound 5 (1.97 g, $0.005 \mathrm{~mol})$ and phosphorus oxychloride $(3 \mathrm{~mL})$ in dioxane $(10 \mathrm{~mL})$, was heated under reflux for $3 \mathrm{~h}$. The reaction mixture was cooled down, diluted with ice-cold water and neutralized with ammonium hydroxide. The precipitate formed was filtered, dried and crystallized from ethanol to yield $63 \%$ of $6 . \mathrm{mp}$ $>350{ }^{\circ} \mathrm{C}$. IR $v_{\max } \mathrm{cm}^{-1}: 3061$ (CH Ar), 2900, 2852 (CH aliphatic), 1691(C=O), 1624, 1610, $1490(\mathrm{C}=\mathrm{N}, \mathrm{C}=\mathrm{C}) .{ }^{1} \mathrm{H} \mathrm{NMR}$ $\left(\mathrm{DMSO}-d_{6}\right) \delta$ ppm: $1.87\left(\mathrm{~s}, 3 \mathrm{H}, \mathrm{CH}_{3}\right), 2.27\left(\mathrm{~s}, 3 \mathrm{H}, \mathrm{CH}_{3}\right.$ at $\left.\mathrm{C} 4\right), 2.43\left(\mathrm{~s}, 3 \mathrm{H}, \mathrm{CH}_{3}\right.$ at C8), $3.96\left(\mathrm{~s}, 2 \mathrm{H}, \mathrm{CH}_{2}\right), 4.75(\mathrm{~s}, 2 \mathrm{H}$, $\mathrm{OCH}_{2}$ ), 7.02 (d, 1H, J=8.9 Hz, H-6 Ar), 7.17 (t, 1H, H-4' Ar), 7.23 (t, 2H, H-3',5' Ar), 7.28 (d, 2H, J= 7.4 Hz, H-2', 6' Ar), 7.63 (s, $1 \mathrm{H}, J=8.8 \mathrm{~Hz}, \mathrm{H}-5 \mathrm{Ar})$. MS m/z \%: $376\left(\mathrm{M}^{+}\right)$100\%. Anal. Calcd. for $\mathrm{C}_{22} \mathrm{H}_{20} \mathrm{~N}_{2} \mathrm{O}_{4}(376.41)$ : Calc.: C, 70.20 ; H, 5.36; N, 7.44. Found: C, 70.39; H, 5.44; N, 7.68.

\subsubsection{2-(3-Benzyl-4,8-dimethyl-2-oxo-2H-benzopyran-7-yl)oxy-N,N'-bis(4-methylphenylsulfonyl)acetohydrazide 7 (Scheme 1)}

A mixture of acid hydrazide $3(1.83 \mathrm{~g}, 0.005 \mathrm{~mol})$, tosyl chloride $(1.06 \mathrm{~g}, 0.01 \mathrm{~mol})$ in ethanol $(20 \mathrm{~mL})$ containing a few drops of acetic acid was heated under reflux for $12 \mathrm{~h}$. The solvent was distilled under vacuum and the residue crystallized from ethanol to yield $35 \%$ of 7. mp 200-203 ${ }^{\circ} \mathrm{C}$. IR $v_{\max }, \mathrm{cm}^{-1}: 3446(\mathrm{NH}), 3032(\mathrm{CH}$ Ar), $2920,2864(\mathrm{CH}$ aliphatic), 1743, $1705(2 \mathrm{C}=\mathrm{O}), 1602,1496,(\mathrm{NH}, \mathrm{C}=\mathrm{C}), 1354,1188\left(2 \mathrm{SO}_{2}\right) .{ }^{1} \mathrm{H}$ NMR (DMSO-d $) \delta$ ppm: $2.24(\mathrm{~s}, 3 \mathrm{H}$, $\mathrm{CH}_{3}$ at $\left.\mathrm{C} 4\right), 2.29\left(\mathrm{~s}, 6 \mathrm{H}, 2 \mathrm{xCH}_{3}\right), 2.42\left(\mathrm{~s}, 3 \mathrm{H}, \mathrm{CH}_{3}\right.$ at $\left.\mathrm{C} 8\right), 3.96\left(\mathrm{~s}, 2 \mathrm{H}, \mathrm{CH}_{2}\right), 4.00\left(\right.$ br s, $1 \mathrm{H}, \mathrm{NH}$, exchanged with $\left.\mathrm{D}_{2} \mathrm{O}\right)$, $4.86\left(\mathrm{~s}, 2 \mathrm{H}, \mathrm{OCH}_{2}\right), 6.96$ (d, 1H, J=9.0 Hz, H-6 Ar), 7.12 (d, 4H, J=8.0 Hz, 2xH-3",5" Ar), 7.17 (t, $1 \mathrm{H}, \mathrm{H}-4^{\prime}$ Ar), 7.23 (t, 2H, H-3',5' Ar), 7.27 (d, 2H, J=7.4 Hz, H-2',6' Ar), 7.50 (d, 4H, J=8.0 Hz, 2xH-2", 6" Ar), 7.62 (d, $1 \mathrm{H}, J=9.0 \mathrm{~Hz}, \mathrm{~Hz}$, H-5 Ar). MS m/z \%: $660\left(\mathrm{M}^{+}\right)$0.55\%. Anal. Calcd. for $\mathrm{C}_{34} \mathrm{H}_{32} \mathrm{~N}_{2} \mathrm{O}_{8} \mathrm{~S}_{2}$ (660.65): Calc.: C, 61.80; H, 4.88; N, 4.24. Found: C, $61.48 ; \mathrm{H}, 4.96 ; \mathrm{N}, 4.41$. 


\subsubsection{7-[2-(3-Amino-5-imino-4,5-dihydropyrazol-1-yl)-2-oxoethoxy]-3-benzyl-4,8-dimethyl-2H-benzopyran-2-one 8 (Scheme 2)}

A mixture of the hydrazide compound $3(1.83 \mathrm{~g}, 0.005 \mathrm{~mol})$ and malononitrile $(0.66 \mathrm{~g}, 0.01 \mathrm{~mol})$ in ethanol (15 mL) was heated under reflux for $18 \mathrm{~h}$. The formed precipitate was filtered, washed with water, dried and crystallized from acetic acid to yield $89 \%$ of $8 . \mathrm{mp} 253-255^{\circ} \mathrm{C}$. IR $v_{\max } / \mathrm{cm}^{-1}: 3504,3448,3404\left(\mathrm{NH}_{2}, \mathrm{NH}\right), 3022(\mathrm{CH} \mathrm{Ar}), 2933(\mathrm{CH}$ aliphatic), 1695, $1678(2 \mathrm{C}=\mathrm{O}), 1627,1514,1452(\mathrm{NH}, \mathrm{C}=\mathrm{C}) .{ }^{1} \mathrm{H}$ NMR $\left(\mathrm{DMSO}-d_{6}\right) \delta p p m: 1.88\left(\mathrm{~s}, 2 \mathrm{H}, \mathrm{CH}_{2}\right.$ pyrazoline), $2.27\left(\mathrm{~s}, 3 \mathrm{H}, \mathrm{CH}_{3}\right.$ at $\left.\mathrm{C} 4\right), 2.43\left(\mathrm{~s}, 3 \mathrm{H}, \mathrm{CH}_{3}\right.$ at $\left.\mathrm{C} 8\right), 3.97\left(\mathrm{~s}, 2 \mathrm{H}, \mathrm{CH}_{2}\right) 4.65(\mathrm{~s}, 1 \mathrm{H}, \mathrm{NH}), 4.77\left(\mathrm{~s}, 2 \mathrm{H}, \mathrm{OCH}_{2}\right)$, 7.00 (d, 1H, J=8.0 Hz, H-6 Ar), 7.18 (t, 1H, H-4' Ar), 7.23 (t, 2H, H-3',5' Ar), 7.28 (d, 2H, J= 7.4 Hz, H-2',6' Ar), 7.64 (d, $1 \mathrm{H}, J=8.0 \mathrm{~Hz}, \mathrm{H}-5 \mathrm{Ar}), 9.93$ (s, $\left.2 \mathrm{H}, \mathrm{NH}_{2}\right)$. MS m/z\%: $420\left(\mathrm{M}^{+}+2\right)$ 2.88\%. Anal. Calcd. for $\mathrm{C}_{23} \mathrm{H}_{22} \mathrm{~N}_{4} \mathrm{O}_{4}(418.45): \mathrm{C}_{\text {, }}$ 66.02; H, 5.30; N, 13.39. Found: C, 66.34; H, 5.35; N, 13.64 .

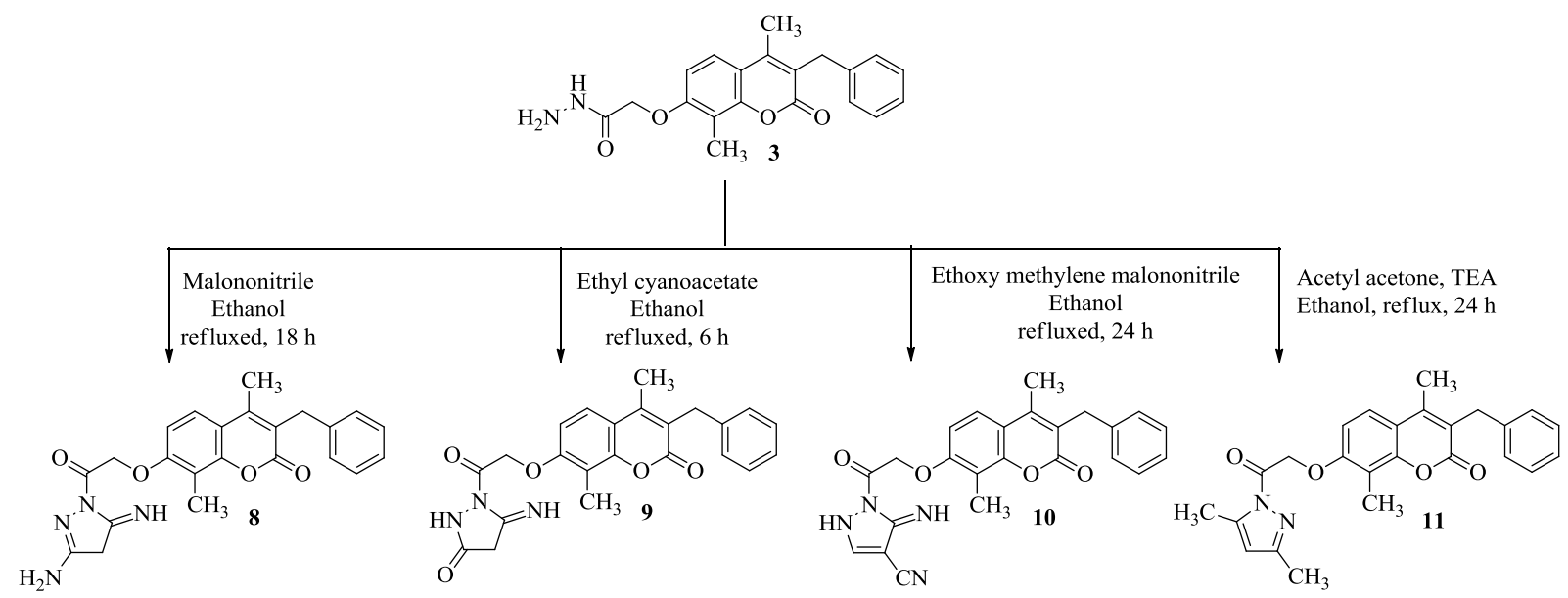

Scheme (2). Synthesis of substituted pyrazoles 8-11.

\subsubsection{1-[2-(3-Benzyl-4,8-dimethyl-2-oxo-2H-benzopyran-7-yl)oxyacetyl]-5-iminopyrazolidin-3-one 9 (Scheme 2)}

A mixture of the acid hydrazide $3(1.83 \mathrm{~g}, 0.005 \mathrm{~mol})$ and ethyl cyanoacetate $(1.13 \mathrm{~mL}, 0.01 \mathrm{~mol})$ in ethanol $(5 \mathrm{~mL})$ was heated under reflux for $6 \mathrm{~h}$. The precipitated solid was filtered, washed, dried and crystallized from ethanol to yield $65 \%$ of 9. $\mathrm{mp} 215-217^{\circ} \mathrm{C}$. IR $v_{\max } \mathrm{cm}^{-1}: 3446,3176$ (2NH), 3059 (CH Ar), 2920, 2840 (CH aliphatic), 1710, 1697 $(3 \mathrm{C}=\mathrm{O}), 1620,1606,1492(\mathrm{NH}, \mathrm{C}=\mathrm{C}) .{ }^{1} \mathrm{H} \mathrm{NMR}\left(\mathrm{DMSO}-d_{6}\right) \delta$ ppm: $1.87\left(\mathrm{~s}, 2 \mathrm{H}, \mathrm{CH}_{2}\right.$ pyrazolone $), 2.26\left(\mathrm{~s}, 3 \mathrm{H}, \mathrm{CH}_{3}\right.$ at C4), $2.43\left(\mathrm{~s}, 3 \mathrm{H}, \mathrm{CH}_{3}\right.$ at C8), $3.96\left(\mathrm{~s}, 2 \mathrm{H}, \mathrm{CH}_{2}\right), 4.76\left(\mathrm{~s}, 2 \mathrm{H}, \mathrm{OCH}_{2}\right), 7.00(\mathrm{~d}, 1 \mathrm{H}, J=8.9 \mathrm{~Hz}, \mathrm{H}-6 \mathrm{Ar}), 7.17$ (t, $1 \mathrm{H}, \mathrm{H}-4{ }^{\prime}$ Ar), 7.23 (t, 2H, H-3',5' Ar), 7.28 (d, 2H, J= 7.4 Hz, H-2',6' Ar), 7.63 (d, 1H, J=8.9 Hz, H-5 Ar), 9.67 (s, 2H, 2xNH). MS m/z \%:419 (M ) 1.18\%. Anal. Calcd. for $\mathrm{C}_{23} \mathrm{H}_{21} \mathrm{~N}_{3} \mathrm{O}_{5}$ (419.43): Calc.: C, 65.86; H, 5.05; N, 10.02. Found: C, 66.14; $\mathrm{H}, 5.19 ; \mathrm{N}, 10.31$.

\subsubsection{1-[2-(3-benzyl-4,8-dimethyl-2-oxo-2H-benzopyran-7-yl)oxyacetyl]-5-imino-2,5-dihydro-1H-pyrazole-4- carbonitrile 10 (Scheme 2)}

A mixture of the acid hydrazide $3(1.83 \mathrm{~g}, 0.005 \mathrm{~mol})$ and ethoxy methylene malononitrile $(1.22 \mathrm{~g}, 0.01 \mathrm{~mol})$ in ethanol $(15 \mathrm{~mL})$ was heated under reflux for $24 \mathrm{~h}$. The solution was concentrated and the precipitated solid was filtered, washed, dried and crystallized from DMF to yield $45 \%$ of 10. mp 200-205 ${ }^{\circ} \mathrm{C}$. IR $v_{\max } \mathrm{cm}^{-1}: 3421,3367$ (2NH), 2929, 2856 (CH aliphatic), $2196(\mathrm{CN}), 1700,1680(2 \mathrm{C}=\mathrm{O}), 1622,1602,1544,1492(\mathrm{C}=\mathrm{N}, \mathrm{NH}, \mathrm{C}=\mathrm{C}) .{ }^{1} \mathrm{H}$ NMR $\left(\mathrm{DMSO}-d_{6}\right)$

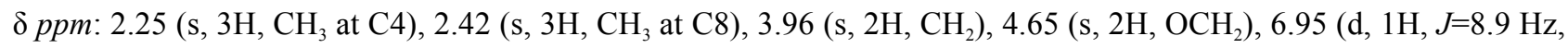
H-6 Ar), 7.15-7.28 (m, 6H, H-Ar, CH pyrazole), 7.62 (d, 1H, J=8.9 Hz, H-5 Ar), 8.62 (s, 1H, NH exchanged with $\mathrm{D}_{2} \mathrm{O}$ ), 9.34 (s, $1 \mathrm{H}$, NH exchanged with $\mathrm{D}_{2} \mathrm{O}$ ). MS m/z \%:427 ( $\left.\mathrm{M}^{+}-1\right)$ 6.04\%. Anal. Calcd. for $\mathrm{C}_{24} \mathrm{H}_{20} \mathrm{~N}_{4} \mathrm{O}_{4}$ (428.44): Calc.: C, 67.28; H, 4.71; N, 13.08. Found: C, 67.51; H, 4.80; N, 13.25. 


\subsubsection{3-Benzyl-7-[2-(3,5-dimethyl-1H-pyrazol-1-yl)-2-oxoethoxy]-4,8-dimethyl-2H-benzopyran-2-one 11 (Scheme 2)}

A mixture of the acid hydrazide $3(1.83 \mathrm{~g}, 0.005 \mathrm{~mol})$ and acetyl acetone $(1 \mathrm{~mL})$ in ethanol containing a few drops of triethylamine was heated under reflux for $24 \mathrm{~h}$. The solution was concentrated and the precipitated solid was filtered, washed, dried and crystallized from DMF to yield $45 \%$ of 7. $\mathrm{mp} 100-101^{\circ} \mathrm{C}$. IR $v_{\max } \mathrm{cm}^{-1}: 3030(\mathrm{CH} \mathrm{Ar}), 2926,2858$ (CH aliphatic), 1743, $1705(2 \mathrm{C}=\mathrm{O}), 1602,1498(\mathrm{C}=\mathrm{C}) .{ }^{1} \mathrm{H}$ NMR (DMSO-d $) \delta$ ppm: $2.26\left(\mathrm{~s}, 3 \mathrm{H}, \mathrm{CH}_{3}\right.$ at $\left.\mathrm{C} 4\right), 2.40(\mathrm{~s}$, $\left.6 \mathrm{H}, 2 \mathrm{xCH}_{3}\right), 2.46\left(\mathrm{~s}, 3 \mathrm{H}, \mathrm{CH}_{3}\right.$ at $\left.\mathrm{C} 8\right), 3.96\left(\mathrm{~s}, 2 \mathrm{H}, \mathrm{CH}_{2}\right), 5.08\left(\mathrm{~s}, 2 \mathrm{H}, \mathrm{OCH}_{2}\right), 5.66(\mathrm{~s}, 1 \mathrm{H}, \mathrm{CH}$ pyrazole $), 6.87(\mathrm{~d}, 1 \mathrm{H}$, $J=8.9$ Hz, H-6 Ar), 7.17 (t, 1H, H-4' Ar), 7.23 (t, 2H, H-3',5' Ar), 7.27 (d, 2H, J = 7.4 Hz, H-2',6' Ar), 7.57 (d, $1 \mathrm{H}$, $J=8.9 \mathrm{~Hz}, \mathrm{H}-5 \mathrm{Ar}) . \mathrm{MS} \mathrm{m} / \mathrm{z} \%$ : $416\left(\mathrm{M}^{+}\right)$1.91\%. Anal. Calcd. for $\mathrm{C}_{25} \mathrm{H}_{24} \mathrm{~N}_{2} \mathrm{O}_{4}$ (416.47): Calc.: C, 72.10; H, 5.81; N, 6.73. Found: C, 71.89; H, 5.89; N, 7.02.

\subsection{Biological Activity}

\subsubsection{Antitumor Screening}

The synthesized compounds were subjected to the NCI's disease-oriented human cell lines screening assay to be evaluated for their in-vitro antitumor activity. The anticancer assays were performed in accordance with the protocol of the Drug Evaluation Branch, NCI, Bethesda [14 - 18].

Under a sterile condition, the human tumor cell lines of the cancer screening panel were grown in RPMI 1640 medium containing 5\% fetal bovine serum and $2 \mathrm{mM}$ L-glutamine. For a typical screening experiment, the cells were inoculated into 96 well microtiter plates in $100 \mu \mathrm{L}$ at plating densities ranging from 5,000 to 40,000 cells/well depending on the doubling time of individual cell lines. After cell inoculation, the microtiter plates were incubated at $37^{\circ} \mathrm{C}, 5 \% \mathrm{CO}_{2}, 95 \%$ air and $100 \%$ relative humidity for $24 \mathrm{~h}$ prior to the addition of experimental drugs.

After $24 \mathrm{~h}$, two plates of each cell line were fixed in situ with trichloroacetic acid (TCA), to represent a measurement of the cell population for each cell line at the time of drug addition $(T z)$. Experimental drugs were solubilized in dimethylsulfoxide (DMSO) at 400-fold achieving the desired final maximum test concentration and stored frozen prior to use. At the time of drug addition, an aliquot of frozen concentrate was thawed and diluted to twice the desired final test concentration $\left(10^{-5} \mathrm{M}\right)$ with complete medium containing $50 \mu \mathrm{g} / \mathrm{mL}$ gentamicin. Aliquots of 100 $\mu \mathrm{L}$ of these drug dilutions were added to the appropriate microtiter wells already containing $100 \mu \mathrm{L}$ of medium, resulting in the required final drug concentrations.

Following drug addition, the plates were incubated for an additional $48 \mathrm{~h}$ at $37^{\circ} \mathrm{C}, 5 \% \mathrm{CO}_{2}, 95 \%$ air, and $100 \%$ relative humidity. For adherent cells, the assay was terminated by the addition of cold TCA. Cells were fixed in situ by gently adding $50 \mu \mathrm{L}$ of cold $50 \%$ (w/v) TCA (final concentration, 10\% TCA) and incubated for $60 \mathrm{~min}$. at $4{ }^{\circ} \mathrm{C}$. The supernatant was discarded, and the plates were washed five times with tap water and air dried. Sulforhodamine B (SRB) solution $(100 \mu \mathrm{L})$ at $0.4 \%(\mathrm{w} / \mathrm{v})$ in $1 \%$ acetic acid was added to each well, and plates were incubated for $10 \mathrm{~min}$ at room temperature. After staining, unbound dye was removed by washing five times with $1 \%$ acetic acid and the plates were air dried. Bound stain was subsequently solubilized with $10 \mathrm{mM}$ trizma base, and the absorbance was read on an automated plate reader at a wavelength of $515 \mathrm{~nm}$ [19].

Using the seven absorbance measurements [time zero, $(T z)$, control growth, $(C)$, and test growth in the presence of drug at the $10^{-5} \mathrm{M}$ concentration level $(\mathrm{Ti})$ ], the percentage growth was calculated at each of the drug concentrations levels. Percentage growth inhibition was calculated as:

$$
\begin{aligned}
& {[(T i-T z) /(C-T z)] \times 100 \text { for concentrations for which } \mathrm{Ti} \geq \mathrm{Tz}} \\
& {[(T i-T z) / T z] \times 100 \text { for concentrations for which } \mathrm{Ti}<\mathrm{Tz} .}
\end{aligned}
$$

\subsubsection{The Mean Graph}

Mean graph is the mean presenting the in vitro test results to emphasize differential effects of test compounds on various human tumor cell lines. It plots the growth relative to no drug control and relative to time zero number of cells. The mean is the average of growth across the tested cell lines, while delta is the maximum difference from the mean. 


\section{RESULTS AND DISCUSSION}

\subsection{Chemistry}

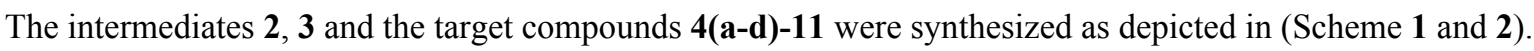

The starting compound $\mathbf{1}$ was prepared as reported in literature [13]. Benzylidene acetohydrazides derivatives were prepared by refluxing acid hydrazide with appropriate aromatic aldehyde or acetophenone in ethanol/ glacial acetic acid, and this method was adopted for the synthesis of compounds $\mathbf{4 a - d}$. The structures of $\mathbf{4 a - d}$ were confirmed with elemental analyses and spectral data. IR spectra elicited a band at $3460-3188 \mathrm{~cm}^{-1}$ corresponding to NH group. ${ }^{1} \mathrm{H}$ NMR of 4a-c displayed a singlet at 7.89-8.22 ppm corresponding to azo methane proton and another singlet at 8.50-11.57 ppm assigned to $\mathrm{NH}$. While compound $4 \mathbf{d}$ revealed a singlet signal at $2.53 \mathrm{ppm}$ corresponding to the $\mathrm{N}=\mathrm{CCH}_{3}$ protons and two singlet signals at 3.81 and $3.84 \mathrm{ppm}$ corresponding to the added two $\mathrm{OCH}_{3}$ protons. Finally, MS spectra revealed their molecular ion peaks. Compound $\mathbf{5}$ was obtained by stirring a mixture of acid hydrazide $\mathbf{3}$ with glacial acetic acid at room temperature for $24 \mathrm{~h}$. The structure of $\mathbf{5}$ was elucidated by the elemental analysis and spectral data. IR spectrum showed bands at $3446,3238 \mathrm{~cm}^{-1}$ corresponding to $2 \mathrm{NH}$ groups. ${ }^{1} \mathrm{H}$ NMR spectrum revealed a singlet signal at $\delta=1.88 \mathrm{ppm}$ corresponding to $\mathrm{COCH}_{3}$ proton and 2 singlet signals at $\delta=9.89$ and $10.04 \mathrm{ppm}$ corresponding to $2 \mathrm{NH}$ groups. The MS spectrum revealed its molecular ion peak at 394. Synthesis of substituted oxadiazoles can be achieved through one pot reaction of three components, phosphorus oxychloride, acid hydrazide and acid derivatives [20]. Another method involves cyclization of acetohydrazide derivatives using phosphorus oxychloride in dioxane [21]. In the present work, the later method was followed to prepare $\mathbf{6}$ in good yield. Compound $\mathbf{6}$ was confirmed through the elemental analysis and spectral data. IR spectrum showed disappearance of bands corresponding to $2 \mathrm{NH}$ groups and only one band at $1691 \mathrm{~cm}^{-1}$ corresponding to benzopyrone $\mathrm{C}=\mathrm{O}$ group. ${ }^{1} \mathrm{H}$ NMR spectrum revealed disappearance of any signals corresponding to the $2 \mathrm{NH}$ protons. MS spectrum showed its molecular ion peak at $\mathrm{m} / \mathrm{z} 367$. Reaction of acid hydrazide derivatives with acid chloride as tosyl chloride led to the formation of benzene sulfone hydrazide derivatives, this reaction was reported to be performed in glacial acetic acid at room temperature for $24 \mathrm{~h}$ [22]. The structure of 7 was deduced as disubstituted derivative by the elemental analysis and spectral data. IR spectrum showed a band at $3446 \mathrm{~cm}^{-1}$ corresponding to NH group and bands at $1354,1188 \mathrm{~cm}^{-1}$ corresponding to $\mathrm{SO}_{2}$ groups. ${ }^{1} \mathrm{H}$ NMR spectrum showed a singlet signal at $\delta=2.29 \mathrm{ppm}$ corresponding to two $p-\mathrm{CH}_{3}$ protons, a double of doublet at $\delta=7.12$ and $7.50 \mathrm{ppm}$ corresponding to $3^{\prime \prime}, 5^{\prime \prime}$ and $2^{\prime \prime}, 6^{\prime \prime}$ protons of the two $p$-methylbenzenesulphone moieties, respectively. The MS spectrum of 7 revealed the molecular ion peak at 660 .

Refluxing acid hydrazide 3 with many substituted carbonitrile derivatives as malononitrile, ethyl cyanoacetate and ethoxy methylene malononitrile was reported to yield the corresponding amino pyrazoles $\mathbf{8}$, pyrazolone $\mathbf{9}$ and pyrazole carbonitriles 10, respectively. The target compounds 8, 9, and $\mathbf{1 0}$ were synthesized through refluxing acid hydrazide derivative $\mathbf{3}$ with appropriate carbonitrile compound in ethanol (Scheme 2).

The IR spectrum of 8 showed bands at 3504, 3448 and $3404 \mathrm{~cm}^{-1}$ assigned to $\mathrm{NH}_{2}$ and $\mathrm{NH}$ groups. ${ }^{1} \mathrm{H}$ NMR spectra of 8 displayed three singlet signals at 1.88 and 4.65 and $9.93 \mathrm{ppm}$ corresponding to $\mathrm{CH}_{2}$ pyrazoline, $\mathrm{NH}$ and $\mathrm{NH}_{2}$, respectively. ${ }^{1} \mathrm{H}$ NMR spectra of 9 revealed two singlet signals at $\delta=1.87$ and $9.67 \mathrm{ppm}$ corresponding to $\mathrm{CH}_{2}$ pyrazolone and two NH protons, respectively. IR spectrum of $\mathbf{1 0}$ revealed a characteristic band at $2196 \mathrm{~cm}^{-1}$ corresponding to the added cyano group. Finally, MS spectra revealed the molecular ion peaks of the titled compounds. Condensation of acid hydrazide with acetyl acetone in ethanol containing triethylamine afforded the corresponding dimethyl pyrazoles 11 (Scheme 2). The structure of 11 was deduced from microanalytical and spectral data. ${ }^{1} \mathrm{H}$ NMR spectra showed new two singlet signals at $2.40 \mathrm{ppm}$ assigned to six protons of the two $\mathrm{CH}_{3}$ substituting the pyrazole ring and at $5.66 \mathrm{ppm}$ corresponding to the $\mathrm{CH}$ of pyrazole, finally $\mathbf{1 1}$ revealed the molecular ion peak at 416 .

\subsection{Antitumor Screening}

\subsubsection{Preliminary In Vitro Antitumor Screening}

Newly synthesized compounds (4a-d, 5, 6, 7, 8, 9, 10 and 11) were selected by National Cancer Institute (NCI) Developmental Therapeutic Program (www.dtp.nci.nih.gov), Bethesda, MD, U.S.A. The synthesized compounds were subjected to the NCI's disease-oriented human cell lines screening assay to be evaluated for their in vitro antitumor activity. The anticancer assays were performed in accordance with the protocol of the Drug Evaluation Branch, NCI, Bethesda [14 - 18]. A single dose $(10 \mu \mathrm{M})$ of the test compounds was used in the full NCI 60 cell line panel assay. A 48 
h drug exposure protocol was used and sulforhodamine B (SRB) protein assay was applied to estimate the cell viability and growth [19]. The results were reported as mean graph of the percent growth of the treated cells and presented as percentage growth inhibition (GI \%). The obtained results of the tested benzopyrone analogues showed distinctive potential pattern of selectivity, as well as broad-spectrum antitumor activity (Table 1).

Table 1. Growth inhibition percent of tested compounds against 60 different cell lines.

\begin{tabular}{|c|c|c|c|c|c|c|c|c|c|c|c|}
\hline \multirow[b]{2}{*}{ Panel/Cell Line } & \multirow{2}{*}{$\frac{-}{4 a}$} & \multicolumn{10}{|c|}{ Test compounds and growth inhibition percent of cell line } \\
\hline & & $4 \mathbf{b}$ & $4 \mathbf{c}$ & $4 d$ & 5 & 6 & 7 & 8 & 9 & 10 & 11 \\
\hline \multicolumn{12}{|l|}{ Leukemia } \\
\hline CCRF-CEM & 19.49 & 15.78 & - & - & - & - & - & - & - & - & - \\
\hline HL-60 (TB) & 30.93 & 23.39 & - & - & - & - & - & - & - & - & - \\
\hline K-562 & - & - & - & - & - & - & - & - & - & - & - \\
\hline MOLT-4 & - & - & 14.21 & - & - & - & - & - & - & - & - \\
\hline RPMI-8226 & - & 13.84 & 24.64 & - & - & - & - & 11.51 & - & - & - \\
\hline SR & 25.42 & 20.78 & 29.69 & - & 15.42 & 12.64 & 11.32 & 17.70 & - & - & - \\
\hline \multicolumn{12}{|c|}{ Non-Small Cell Lung Cancer } \\
\hline A549/ATCC & - & 20.29 & 17.33 & - & - & - & - & 10.33 & - & - & - \\
\hline EKVX & - & - & - & - & - & - & - & - & - & - & - \\
\hline HOP-92 & 46.05 & 17.44 & 11.58 & - & - & - & - & 14.05 & 15.45 & 10.92 & - \\
\hline NCI-H226 & 15.35 & 14.88 & 17.63 & - & - & - & - & - & 12.25 & - & - \\
\hline NCI-H23 & - & 12.03 & 10.10 & - & - & - & - & - & - & - & - \\
\hline NCI-H322M & 22.25 & 13.99 & 12.49 & - & - & - & - & 20.33 & 20.19 & - & - \\
\hline NCI-H460 & - & - & - & - & - & - & - & - & - & - & - \\
\hline NCI-H522 & 19.71 & 22.18 & 31.83 & - & 13.08 & 10.75 & 15.72 & 22.46 & 21.43 & 20.63 & 12.22 \\
\hline \multicolumn{12}{|l|}{ Colon Cancer } \\
\hline COLO 205 & - & - & - & - & - & - & - & - & - & - & - \\
\hline HCC-2998 & - & - & - & - & - & - & - & - & - & - & - \\
\hline HCT-116 & - & 13.60 & - & - & - & - & - & - & - & - & - \\
\hline HCT-15 & - & - & - & - & - & - & - & - & - & - & - \\
\hline HT29 & - & - & - & - & - & - & - & - & - & - & - \\
\hline KM12 & - & 10.00 & - & - & - & - & - & - & - & - & - \\
\hline SW-620 & - & - & - & - & - & - & - & - & - & - & - \\
\hline \multicolumn{12}{|l|}{ CNS Cancer } \\
\hline SF-268 & 15.28 & 11.01 & - & - & - & - & - & - & - & - & - \\
\hline SF-295 & - & 13.86 & - & - & - & - & - & - & - & - & - \\
\hline SF-539 & - & 12.74 & - & - & - & - & - & - & - & - & - \\
\hline SNB-19 & 11.02 & - & 10.74 & - & - & - & - & - & - & - & - \\
\hline SNB-75 & - & 44.61 & 13.03 & - & - & - & - & - & - & 19.00 & - \\
\hline U251 & 10.69 & 10.79 & - & - & - & - & - & - & - & - & - \\
\hline \multicolumn{12}{|l|}{ Melanoma } \\
\hline LOX IMVI & 21.11 & - & 11.55 & - & - & - & - & - & - & - & - \\
\hline MALME-3M & - & 16.27 & - & - & - & - & - & - & - & - & - \\
\hline M14 & - & - & - & - & - & - & - & - & - & - & - \\
\hline MDA-MB-435 & - & - & - & - & - & - & - & - & - & - & - \\
\hline SK-MEL-2 & - & - & - & - & - & - & - & - & - & - & - \\
\hline SK-MEL-28 & - & - & - & - & - & - & - & - & - & - & - \\
\hline SK-MEL-5 & - & - & 12.50 & - & - & - & - & - & - & - & - \\
\hline UACC-257 & 12.95 & 21.41 & 12.10 & - & - & - & - & - & - & - & - \\
\hline UACC-62 & - & - & 23.91 & - & - & - & - & - & - & - & - \\
\hline \multicolumn{12}{|l|}{ Ovarian cancer } \\
\hline IGROV1 & - & - & 10.63 & - & - & - & - & - & 16.75 & - & - \\
\hline OVCAR-3 & - & 10.81 & - & - & - & - & - & - & - & - & - \\
\hline OVCAR-4 & - & 15.15 & - & - & - & - & - & - & - & - & - \\
\hline OVCAR-5 & - & - & - & - & - & - & - & - & - & - & - \\
\hline
\end{tabular}


(Table 1) contd.....

\begin{tabular}{|c|c|c|c|c|c|c|c|c|c|c|c|}
\hline \multirow[b]{2}{*}{ Panel/Cell Line } & \multirow{2}{*}{$\frac{-}{4 a}$} & \multicolumn{10}{|c|}{ Test compounds and growth inhibition percent of cell line } \\
\hline & & $4 \mathbf{b}$ & $4 c$ & 4d & 5 & 6 & 7 & 8 & 9 & 10 & 11 \\
\hline OVCAR-8 & - & 15.93 & - & - & - & - & - & - & - & - & - \\
\hline NCI/ADR-RES & - & - & - & - & - & - & - & - & - & - & - \\
\hline SK-OV-3 & - & - & - & - & - & - & - & - & - & - & - \\
\hline \multicolumn{12}{|l|}{ Renal cancer } \\
\hline $786-0$ & - & - & - & - & - & - & - & - & - & - & - \\
\hline A498 & 15.27 & 14.27 & 10.90 & - & - & - & - & - & - & - & - \\
\hline $\mathrm{ACHN}$ & - & & - & - & - & - & - & - & - & - & - \\
\hline RXF 393 & - & 18.22 & - & - & - & - & - & - & - & - & - \\
\hline SN12C & 10.23 & - & - & - & - & - & - & - & - & - & - \\
\hline TK-10 & - & - & - & - & - & - & - & - & - & - & - \\
\hline UO-31 & 28.13 & - & 34.48 & 15.52 & 21.08 & 11.03 & 21.24 & 29.22 & 35.81 & 24.45 & 15.14 \\
\hline \multicolumn{12}{|l|}{ Prostate cancer } \\
\hline PC-3 & 11.26 & 18.85 & 18.92 & - & - & - & - & - & 14.89 & 11.04 & - \\
\hline DU-145 & - & - & - & - & - & - & - & - & - & - & - \\
\hline \multicolumn{12}{|l|}{ Breast cancer } \\
\hline MCF7 & 10.65 & 10.50 & 14.72 & - & - & - & - & 10.44 & - & 10.28 & - \\
\hline MDA-MB-231/ATCC & 13.56 & 21.06 & 17.25 & - & - & - & - & - & - & - & - \\
\hline HS 578T & - & 11.68 & 10.07 & - & - & - & - & - & - & - & - \\
\hline BT-549 & - & - & - & - & - & - & - & 13.86 & - & - & - \\
\hline $\mathrm{T}-47 \mathrm{D}$ & - & 19.15 & 30.04 & - & - & - & - & 29.36 & - & 18.11 & - \\
\hline MDA-MB-468 & - & - & - & - & - & - & - & - & - & - & - \\
\hline Mean GI\% & 6.17 & 10.84 & 7.99 & 0.00 & 0.00 & 0.00 & 0.00 & 3.66 & 2.08 & 0.95 & 0.00 \\
\hline
\end{tabular}

$(-, \mathrm{GI}<10 \%)$

Regarding the activity towards individual cell lines, Schiffs like compounds 4 a-d showed overall moderate activity with 4a-c having a better activity with mean GI values of $6.17,10.84$ and $7.99 \%$ for $\mathbf{4 a}$, $\mathbf{4 b}$ and $\mathbf{4 c}$, respectively compared to $\mathbf{4 d}$. Regarding the activity of each compound, the benzylidene derivative 4 a achieved only a moderate effect upon leukemia HL-60 (TB) with GI value of 30.93\% and a weak activity over the leukemia subpanels CCRFCEM and SR with GI values of 19.49 and $25.42 \%$, respectively. A noticeable effect was achieved upon many non-small cell lung cancer subpanels with cell line NCI-H226 having the greatest effect of GI value of $46.05 \%$ while NCI-H23, NCI-H332M and NCI-H522 was inhibited by values of 15.35, 22.25 and 19.71\%, respectively. An overall weak activity was revealed over the other subpanels tested with GI values of 15.28, 11.02, 10.69, 21.11, 12.95, 15.27, 10.23, 28.13, 11.26, 10.65 and 13.56 for CNS cancer subpanels SF-268, SNB-19, U251, melanoma subpanels LOXIMVIMALME-3M, UACC-62, ovarian cancer OVCAR-8, renal cancer A498, SN12C, UO-31, prostate cancer PC-3 and finally breast cancer MCF-7 and MDA-MB-231/ATCC, respectively. The 4-methoxybenzylidene derivative 4b revealed similar activity to that of the $N, N$-dimethylaminobenzylidene derivative 4a with the highest effect achieved over the CNS cancer subpanel SNB-75 with GI value of $44.61 \%$. The other cell lines tested were inhibited with weak to moderate effect with GI values of $15.78,23.39,13.84$ and $20.78 \%$ for leukemia cell lines CCRF-CEM, HL-60 (TB), MOLT-4 and RPMI-8226, respectively. While the non-small cell lung cancer subpanels A549/ATCC, HOP-92, NCIH226, NCI-H23, NCI-H322M and NCI-H522 with GI values of 17.44, 14.88, 12.03, 13.99 and 22.18\%, respectively. Colon cancer subpanels HCT-116 and KM12 were inhibited by GI values of 13.60 and $10.00 \%$, respectively. A moderate effect was achieved upon melanoma subpanel UACC-257 with GI value of $21.41 \%$, the renal cancer RXF393 with GI value of $18.22 \%$ and prostate cancer cell line PC-3 was inhibited by $21.06 \%$. Finally, GI values of 21.06 and 19.15\% were achieved over breast cancer subpanels MDA-MB-231/ATCC and MDA-MB-468, respectively. The trimethoxybenzylidene 4c inhibited leukemia subpanels RPMI-8226 and SR with GI values of 24.64 and 29.69\%. A good effect was shown upon the non-small cell lung cancer subpanel NCI-H522 with GI value of 31.83\%. GI values of 34.48 and 30.04\% were achieved over renal cancer UO-31 and breast subpanel MDA-MB-468, respectively. The dimethoxyphenylethylidene derivative $\mathbf{4 d}$ showed a weak activity over a single cell line, the renal cancer UO-31 with GI value of $15.52 \%$.

The acetohydrazide derivative 5, oxadiazole 6 and bis-methylphenylsulphonyl derivative 7 showed a similar inhibitory pattern. The three compounds revealed only a weak effect upon leukemia subpanel RPMI-8226 with GI values of 15.42, 12.64 and $11.32 \%$ for 5, $\mathbf{6}$ and 7, respectively. Also the non-small cell lung cancer cell line NCI-H522 
was inhibited by $13.08,10.75$ and $15.72 \%$ for $\mathbf{5 , 6}$ and 7, respectively. Finally, 5, $\mathbf{6}$ and $\mathbf{7}$ exhibited a weak activity over renal cancer UO-31 with GI values of $21.08,11.03$ and $21.24 \%$, respectively.

The 3-amino-5-imino-4,5-dihydropyrazol 8 derivative, 5-iminopyrazolidin-3-one derivative 9 and 5-imino-2,5dihydropyrazole-4-carbonitrile $\mathbf{1 0}$ revealed no noticable effect, all three derivatives shared activity towards non-small cell lung cancer subpanel NCI-H522 with GI values 22.46, 21.43 and 20.63\%, respectively, they also shared activity towards renal cancer UO-31 with GI values of 29.22, 35.81 and $24.45 \%$, respectively. 8 also possessed weak activity towards breast cancer T-47D with GI value of $29.36 \%$ where it showed the highest mean GI among the three derivatives of value $3.66 \%$ compared to mean GI value of 2.08 and $0.95 \%$ corresponding to 9 and $\mathbf{1 0}$, respectively. Compound 11 did not exhibit considerable activity as GI values were 12.22 and 15.14\% against non-small cell lung cancer NCI-H522 and renal cancer UO-31, respectively.

\section{CONCLUSION}

New benzopyrone derivatives were prepared in this study. All compounds were selected by National Cancer Institute (NCI), Bethesda, and evaluated for their in vitro anticancer activity in the full NCI 60 cell lines panel assay by a single dose test $(10 \mu \mathrm{M})$. Substituted benzylidene derivatives $\mathbf{4 a}, \mathbf{b}$ and $\mathbf{c}$ had the best activity with mean GI values of $6.17,10.84$ and $7.99 \%$, respectively. Results revealed that, Schiff's like compounds of benzopyrone scaffold with substituted benzylidene derivatives 4a-c had overall good effect. However, Schiff's like compounds comprised of disubstituted phenylethylidene derivative $\mathbf{4 d}$ had no significant effect. In addition, aetohydrazide derivatives $\mathbf{5}$ and $\mathbf{7}$ or hybrids with oxadiazole 6 or substituted pyrazoles 8-11 had a weak or no significant effect.

\section{ETHICS APPROVAL AND CONSENT TO PARTICIPATE}

Not applicable.

\section{HUMAN AND ANIMAL RIGHTS}

No Animals/Humans were used for studies that are base of this research.

\section{CONSENT FOR PUBLICATION}

Not applicable.

\section{CONFLICT OF INTEREST}

This research did not receive any specific grant from funding agencies of the public, commercial, or not-for-profit sectors.

The authors declare no conflict of interest, financial or otherwise.

\section{ACKNOWLEDGEMENTS}

Thanks to the NCI, Bethesda, MD, for performing the antitumor testing of the synthesized compounds.

\section{REFERENCES}

[1] Hejmadi, M. Introduction to cancer biology, $2^{\text {nd }}$ ed.; , 2010, p. 6.

[2] Wells, A. Cell Motility in cancer invasion and metastasis, cancer metastasis: Biology and treatment; , 2006, 8, pp. 2-3. [http://dx.doi.org/10.1007/b103440]

[3] Murray, R.D.; Mendez, J.; Brown, S.A. The natural coumarins. Occurrence, chemistry and biochemistry; John Wiley and Sons: Chichester, 1982, Vol. 5, pp. 1-22.

[4] Malini, B.; Purohit, A.; Ganeshapillai, D.; Woo, L.W.; Potter, B.V.; Reed, M.J. Inhibition of steroid sulphatase activity by tricyclic coumarin sulphamates. J. Steroid Biochem. Mol. Biol., 2000, 75(4-5), 253-258. [http://dx.doi.org/10.1016/S0960-0760(00)00178-3] [PMID: 11282279]

[5] Lloyd, M.D.; Pederick, R.L.; Natesh, R.; Woo, L.W.; Purohit, A.; Reed, M.J.; Acharya, K.R.; Potter, B.V. Crystal structure of human carbonic anhydrase II at 1.95 A resolution in complex with 667-coumate, a novel anti-cancer agent. Biochem. J., 2005, 385(Pt 3), 715-720. [http://dx.doi.org/10.1042/BJ20041037] [PMID: 15453828]

[6] Seidel, C.; Schnekenburger, M.; Zwergel, C.; Gaascht, F.; Mai, A.; Dicato, M.; Kirsch, G.; Valente, S.; Diederich, M. Novel inhibitors of human histone deacetylases: design, synthesis and bioactivity of 3-alkenoylcoumarines. Bioorg. Med. Chem. Lett., 2014, 24(16), 3797-3801. [http://dx.doi.org/10.1016/j.bmcl.2014.06.067] [PMID: 25042254] 
[7] Jerris, J.P.; Smith, A.B. Synthesis and configurational assignment of geiparvarin: A novel antitumor agent. J. Org. Chem., 1981, 46, 577-585. [http://dx.doi.org/10.1021/jo00316a018]

[8] Salahuddin, S.M.; Mazumder, A.; Ashan, M.J. Synthesis, characterisation and anticancer evaluation of 2-(naphthalen-1-ylmethyl/ naphthalen-2-yloxymethyl)-1-(5-substituted phenyl)-(1,3,4)oxadiazol-2-ylmethyl)-1H-benzimidazole. Arab. J. Chem., 2013, 7(4), 419-424.

[9] Dawood, K.M.; Eldebss, T.M.; El-Zahabi, H.S.; Yousef, M.H.; Metz, P. Synthesis of some new pyrazole-based 1,3-thiazoles and 1,3,4thiadiazoles as anticancer agents. Eur. J. Med. Chem., 2013, 70, 740-749.

[http://dx.doi.org/10.1016/j.ejmech.2013.10.042] [PMID: 24231309]

[10] Aydın, S.; Kaushik-Basu, N.; Özbaş-Turan, S.; Akbuğa, J.; Mega, T.P.; Orun, O.; Gurukumar, K.R. B, Amartya.; Küçükgüzel, Ş. G. Synthesis of 1-aroyl-3,5-dimethyl-1H-pyrazoles as anti-HCV and anticancer agents. Lett. Drug Des. Discov., 2014, 11(2), 121-131. [http://dx.doi.org/10.2174/15701808113109990069]

[11] Nitulescu, G.M.; Draghici, C.; Olaru, O.T. New potential antitumor pyrazole derivatives: synthesis and cytotoxic evaluation. Int. J. Mol. Sci., 2013, 14(11), 21805-21818 [http://dx.doi.org/10.3390/ijms141121805] [PMID: 24192822]

[12] Eweas, A.F.; Khalifa, N.M.; Ismail, N.S.; Al-Omar, M.A.; Soliman, A.M. Synthesis, molecular docking of novel 1,8-naphthyridine derivatives and their cytotoxic activity against HepG2 cell lines. Med. Chem. Res., 2014, 23, 76-86. [http://dx.doi.org/10.1007/s00044-013-0604-6]

[13] Shilin, S.V.; Garzad, M.M.; Khilya, V.P. Synthesis of dipeptide derivatives of 3,4-substituted 7-hydroxycoumarins. Chem. Nat. Compd., 2008, 44(3), 301-305. [http://dx.doi.org/10.1007/s10600-008-9047-6]

[14] Boyd, M.R.; Paull, K.D. Some practical considerations and applications of the national cancer institute in vitro anticancer drug discovery screen. Drug Dev. Res., 1995, 34, 91-109. [http://dx.doi.org/10.1002/ddr.430340203]

[15] Grever, M.R.; Schepartz, S.A.; Chabner, B.A. The National Cancer Institute: cancer drug discovery and development program. Semin. Oncol., 1992, 19(6), 622-638

[PMID: 1462164]

[16] Monks, A.; Scudiero, D.; Skehan, P.; Shoemaker, R.; Paull, K.; Vistica, D.; Hose, C.; Langley, J.; Cronise, P.; Vaigro-Wolff, A. Feasibility of a high-flux anticancer drug screen using a diverse panel of cultured human tumor cell lines. J. Natl. Cancer Inst., 1991, 83(11), 757-766. [http://dx.doi.org/10.1093/jnci/83.11.757] [PMID: 2041050]

[17] El-Ansary, S.L.; Hussein, M.M.; Abdel Rahman, D.E.; Abdel Ghany, L.M. Synthesis, docking and in vitro anticancer evaluation of some new benzopyrone derivatives. Bioorg. Chem., 2014, 53, 50-66. [http://dx.doi.org/10.1016/j.bioorg.2014.02.003] [PMID: 24607350]

[18] Bhaskar, V.H.; Mohite, P.B.; Synthesis, P.B. Characterization and evaluation of anticancer activity of some tetrazole derivatives. J. Optoelectronics Biomed. Mat, 2010, 2, 249-259.

[19] Skehan, P.; Storeng, R.; Scudiero, D.; Monks, A.; McMahon, J.; Vistica, D.; Warren, J.T.; Bokesch, H.; Kenney, S.; Boyd, M.R. New colorimetric cytotoxicity assay for anticancer-drug screening. J. Natl. Cancer Inst., 1990, 82(13), 1107-1112. [http://dx.doi.org/10.1093/jnci/82.13.1107] [PMID: 2359136]

[20] Ismail, M.M.; Rateb, H.S.; Hussein, M.M. Synthesis and docking studies of novel benzopyran-2-ones with anticancer activity. Eur. J. Med. Chem., 2010, 45(9), 3950-3959. [http://dx.doi.org/10.1016/j.ejmech.2010.05.050] [PMID: 20580139]

[21] Sarhan, A.W. On the synthesis and reactions of indole-2-carboxylic acid hydrazide Monatshefte. Fur. Chemie., 2001, 132, 753-763.

[22] Yassin, F.A.; Seleim, A.F. Synthesis and reactions of oxadiazolo, thiadiazolo and triazolo phthalazin- 1(2H)-one derivatives. Pharma Chem., 2012, 4(3), 860-866.

(C) 2017 El-Ansary et al.

This is an open access article distributed under the terms of the Creative Commons Attribution 4.0 International Public License (CC-BY 4.0), a copy of which is available at: https://creativecommons.org/licenses/by/4.0/legalcode. This license permits unrestricted use, distribution, and reproduction in any medium, provided the original author and source are credited. 